Historic, Archive Document

Do not assume content reflects current scientific knowledge, policies, or practices. 



\section{The PROOF of the}

ASPARAGUS IS IN THE

G R OW IN G

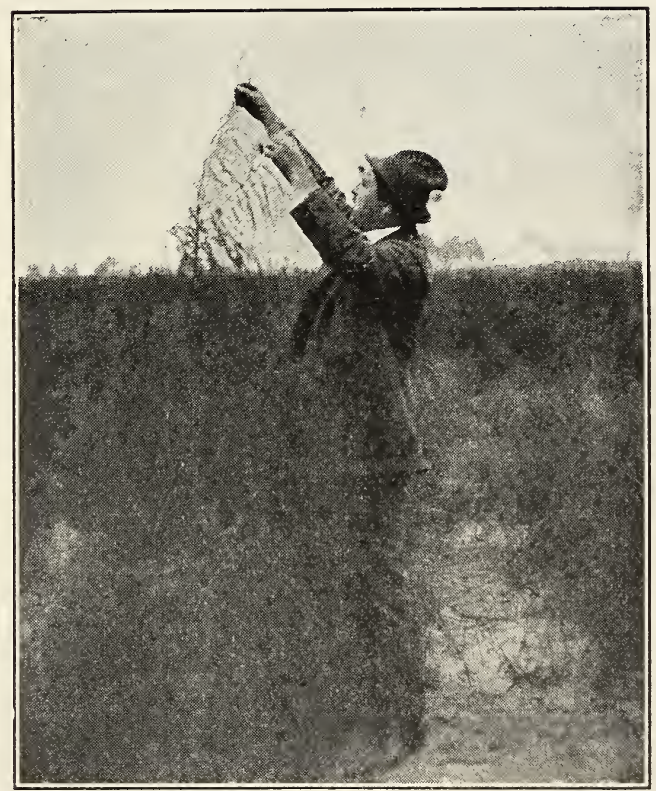

Giant Washington Asparagus

We are pleased to present to you the testimonials within. They are only a few of many and have not been especially selected except for location and climate.

RIVERVIEW FARIIS (Jos. C. Shoemaker) Bridgeton, N. J., U. S. A. 



\section{GIANT WASHINGTON ASPARAGUS}

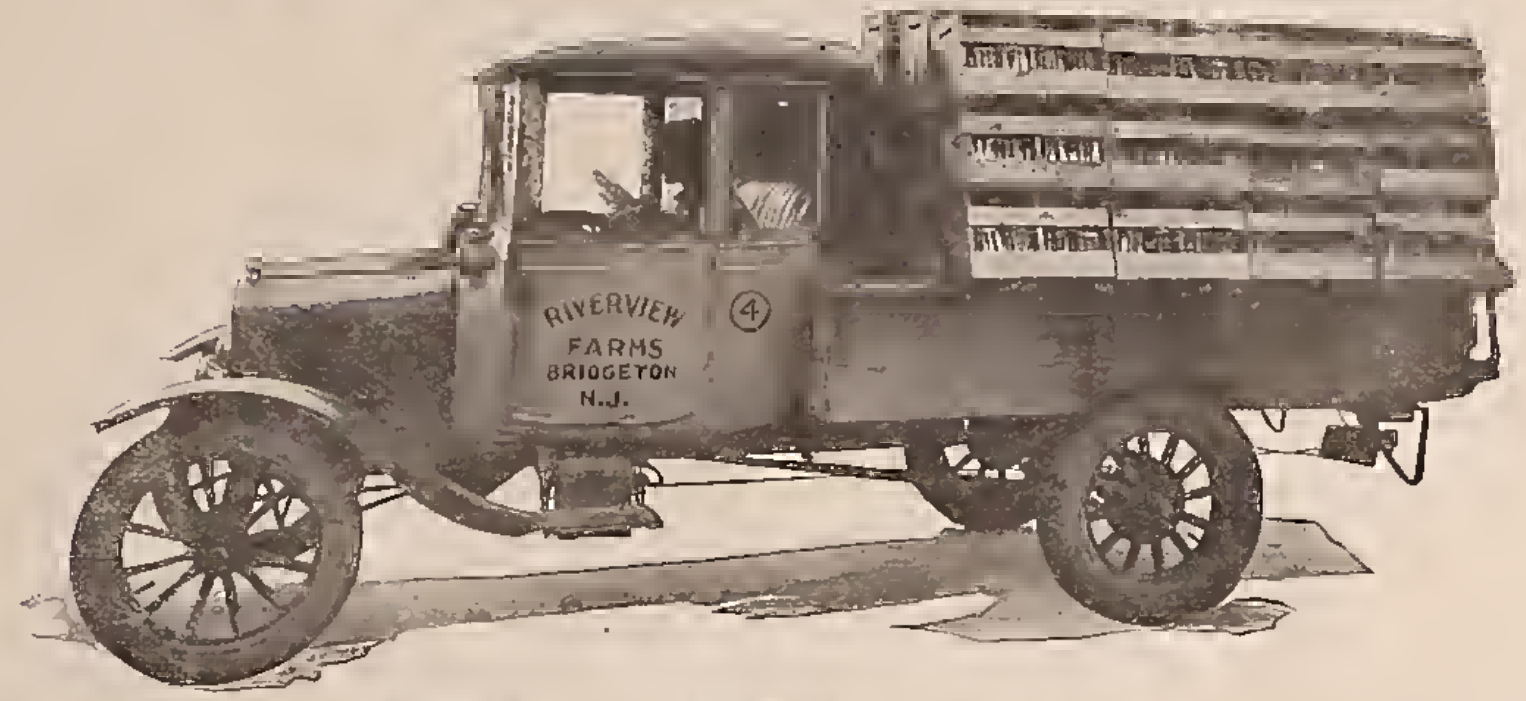

\section{FACTS - FIGURES - PROFITS}

Sale Price of this load in New York Market May 5, 1924-\$601.50. This load was not special-it was an awerage of the "Field Run" for the day, consisting of:

$$
\begin{aligned}
& 9 \text { Crates "Colossal Grade" Gian } \\
& 24 \text { ": "Extra Fancy Grade" } \\
& 17 \text { ". "Fancy Grade". } \\
& \frac{4}{54} \text { Crates "Choice Grade" }
\end{aligned}
$$

Number of Crates - 54 crates.

Weight of Asparagus-1944 liss. net.

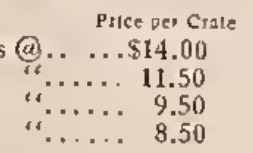

$$
\text { ". }
$$

Average Price per pound-30c ib.

\section{Sale Price Grade Petcertaze}

$\$ 126.00$

280.00

161.50

34.00

$\$ \overline{601.50}$

\section{RIVERVIEW FARMS}

\section{Bridgeton (CUMBERLAND COUNTY) NeW Jersey}

\section{MONTGOMERY COUNTY} FARM BUREAU

HILLSBORO, ILLINOIS

\section{March 4, 1926}

RIverview Farmo,

Bridgeton, New Jersey.

Gentlemen:

Last year I hought 1000 Wash. ington Glant asparagus roots from you whlch were the finest roota 1 ever anw and they made good growth, at lesst nlnety percent of them gTew.

Think I ahall want more tliss sprlng. Kindly send prlce llot.

Yours truly,

R. E. GIFFORD, Secretary.

\section{GEO. E. STOCKING CANNING FACTORY}

ROCHELLE, ILLINOIS

March 5, 1925.

Riverview Farms, Bridgeton, New Jersey.

(Attention Mr. Joseph C. Shoemaker)

\section{Dear Sirs:-}

The spring of 1924 we purchased from your company two carloads consisting of one hundred and five thousand Giant Washington Asparagus Roots, each. Total shipment 210,000 Giant Washington Asparagus Roots. The roots arrived in first-elass eondition and were planted in our fields which we operate for canning purposes under the label of "Stacking's Fancy Natural Asparagus."

I have had the personal supervision of all planting sinee the cvolution of our fields and will state that I have never seen a one year old asparagus root that would equal in size and vitality thc ones we reccived from you and cannot recommend them too highly.

Any one considcring planting asparagus on a seale large enough to rcquire horsedrawn implements, I will state that it is vory cssential and eeonomical to plant the largest and healthiest roots available as a smallcr root necessitates slower and more painstaking cultivation which is a money loser from the standpoint of labor.

My letter of even date will substantiate our. satisfaction in our dealings with your company in the past inasmuch as it approves the fifty samples you sent us to show the class of roots you would be able to furnish us on our contract for one hundred and fifty thousand for delivery in the spring of 1925.

$$
\text { Yours very truly, }
$$

\section{SHALLCROSS BROS.}

Graln, Fertilizers, LIme, Feed, Coal and Farming Implements

MIddletown, Del., Jan. 21, 1924.

Riverview Farms

Bridgeton, N. J.

Gentlemen:-

You will recall that we bought 60,000 1-year old, No. I Washing. ton asparagus roots from you last Spring, and this is to advise you that they were the finest lot of as. paragus roots that we ever saw. We ald not suppose lt was possible to grow 1 year roots as large as these vere.

Our field at the end of the Seas. on looked llike a three year old rather than a I year old fleld and the writer counted rineteen shoots that put up from one crown and any number of crowns that put up filteen shoots or better.

Yours truly,

SHALLCROSS BROTHERS, Per E. HI. Shallcross. 
Eilrly in this rear I ordered from rou some Giant Washington Asparagus roots and receired them in due time. I want to say that they came through in fine shape and were placed in $\mathrm{my}$ garden and every root produced a good strong plant. We find them spreading and producing a nice bunch of new canes and it looks as tho we will be able to gather a nice crop next year. We are certainly pleased with them and if at any time we want to extend our supply of asparagus we certainly will come to you for this same plant.

$$
\text { Yours very truly, D. Van Gieson. }
$$

Gentlemen :

EL PASO, Texas., Feb. 16, 1924.

We got more and better asparagus from your 12 roots last year than from 200 bought locally.

Please find $\$ 5.00$ (P. O. order) and send me 50 roots by return mail. Respectfully. ANNA EKOLS.

\section{* *}

Woodlawn Farm, HOPKINSVILLE. KY.

Riverview Farms,

Feb. 26, 1925

Bridgeton, N. J.

Dear Sir:

Last Spring I ordered from you fifty of your No. 1 Giant Washington Asparagus Roots and recelved fiftytwo fine healthy roots. I prepared my ground and planted according to your directions and every root grew and thrived. The shoots sent up were so large and luscious that it was with difficulty that I refrained from beginning to cut Many of the roots sent up from ten to fourteen thrifty stalks and I am looking forward with pleasure to the coming season.

A little later I expect to send you another order.

Yours truly.

MRS. HOLLAND GARNETT.

$$
\text { * * }
$$

MONTGOMERY, Ala., Feb. 26, 1925.

\section{Riverview Farms, Bridgeton, N. J.}

\section{Gentlemen :}

Last year I purchased some of your Giant Washington asparagus roots, which were planted according to your directions and was very gratified to have them come up $100 \%$. Of course no cuttings were made last season but I am anticipating an abundance of asparagus tips this spring.

Wishing you much success, I am Yours rery truly,

$$
\text { F. P. BOSWELL, M. D. }
$$

Dear Sirs:-

CRISTOBAL, Canal Zone, August 1, 1923

We are pleased to be known as one of your satisfled customers as the Asparagus seed that we obtained from you came up rery nicely, and is growing well.

We are engaged in Agriculture under Tropical conditions and the raising of Asparagus as far as we know has never before been undertaken in this country and is therefore only an experiment on our part and we will be glad to inform you as to our success if sou are interested. Fours truly, OLIVER A. LaPOINTE.

\section{California to Sweden}

Messrs :

$$
\text { LATON, Cal., July 24, } 1923 .
$$

Last spring I receired from you a number of Giant Washington Asparagus roots. I am glad to say that their growth has been phenomenal. Every root grew. The plants are now orer three feet high with 13 to 16 stalks to the hill. Your advice regarding their cultivation has been of great benefit to me. Please accept my thanks for 5our many courtesies. Yours truly,

DR. CHAS. W. HARDMAN.

\section{***}

Gentleman :-

RIVERSIDE, Calif., July 31, 1923.

In regard to Giant Washington Asparagus seed. I don't believe one could get a better stand of plants than mine. 'The plants are large and making a fine growth.

I am satisfied in every way and if in the market for any more seed will know where to get it.

$$
\text { Respectfully, E. A. KING. }
$$


HARRISON, Sioux Co., Neb., Aug. 29, 1923.

You may include my name in your "List of satisfied customers" in your literature and I can assure you I was satisfied. Every seed of the Giant Washington Asparagus came up and is doing nicely, which is going some as we live in the semi-arid country.

Am more than pleased with your manner of doing business.

Respectfuliy, MRS. K. C. GILBERT.

MARIE, Ark., Mar. 3, 1925.

Riverview Farms, Bridgeton, N. J.

Gentlemen :

Last Spring I received 50 Giant Asparagus Roots and they grew to a wonderful size. I can hardly wait for Spring time again so I can see what success I may have with them.

Do not have your prices on Pan-American Blackberry plants. Wish to try some this season.

Yours truly,

MRS. O. M. HILL

***

Riverview Farms,

GOODLAND, Kans., July 25, 1923.

Gentlemen :-

Early last spring I sent for 25 roots of your Giant Washington Asparagus and received 30 fine roots and set them as directed and have a fine bed, every root doing fine. I believe you are as I have always tried to be, on the square. Wishing you best of success, I am

Yours truly, FRED HUNT.

ST. JOSEPH, Mo., July 1, 1923.

Riverview Farms. Bridgeton, N. J.

Gentlemen :-

In repiy to your letter of July 15 , am pleased to advise that all the Giant Washington Asparagus plants, which were planted this spring, came up and are growing beautifully. They are very vigorous and strong plants and look very promising. We shall follow your instructions and expect fine results.

Cordially yours, W. F. UHLMAN.

\section{* * *}

RYAN, Iowa, July 21, 1923.

Riverview Farms, Bridgeton, N. J.

Dear Sirs:-

As regards asparagus roots, I purchased of you, I find 22 out of 24 have made a good healthy growth on their first year. My neighbor says that he planted asparagus roots 2 years ago without getting any growth, so I have reason to be satisfied.

Dr. M. C. CUMMINGS.

$$
* *
$$

MURRYSVILLE, Pa., Feb. 23, 1925.

Riverview Farms, Bridgeton, N. J.

Gentlemen :

A year ago you shipped me several hundred Washington Asparagus Plants. They came in pink of-cond1tion. As to size, quality and 'going' power I found them ideal. Any one failing on such plants must lack the knowledge or the place.

Yours very truly

WILLIAM h. GALLAHER.

P. S.-Mr. Shoemaker: You may "tell the world." Wm. H. G.

NORTH NEIVPORT, N. H., Feb. 23, 1925.

Riverview Farms, Bridgeton, N. J.

Mr. Joseph C. Shoemaker,

Dear Sir:

Out of the 450 Giant Washington Asparagus Roots bought of you last Spring, I don't think that more than six failed to live. I gave three of my neighbors some roots I had to spare and they report every one lived.

I expect to put out about a hundred or a hundred and fifty more plants this Spring.

Yours respectfully,

EDIVARD S. ARNOI,D

Riverview Farms, Bridgeton, N. J., U. S. A. 
Dear Sir:

STRATHAM, N. H., Feb. 24, 1925.

The Giant Washington Asparagus seed I bought from you two years ago done very well. I grew some very nice roots and they looked very well last fall.

The seed I got last year I planted earlier and grew extra nice roots. I could of sold all my roots last Spring. I found the seed just as you told me they would be. I was pleased in every way.

Yours truly,

***

L. M. HILL

Riverview Farms,

DIXFIELD, Me., Feb. 25, 1925.

Bridgeton, N. J.

The 50 GIAN'T WASHINGTON asparagus plants that I purchased last spring, were the best I ever saw. Every plant lived and made a remarkable growth. I take pleasure in recommending your plants and guaranteo a satisfied customer of all who buy them.

$$
\text { Sincerely, }
$$

MRS. JOHN A. BABB

* *

HOLYOKE, Mass., July 18, 1923.

Riverview Farms, Bridgeton, N. J.

Gentlemen :-

In reply to your letter dated July 15th; so far I have had very good results from the Giant Washington Asparagus Plants that I purchased from you last spring. Most of the plants have made a fine growth and are sending out large sturdy stalks. Some of these are more than one half inch in diameter which it seems to me is a good size for year old plants. A neighbor set ont some plants of another variety at the same time I did and his plants are less than one third the size of mine. It is only fair to say however that he has not taken the same care of his bed that I have taken of mine. I followed your instructions carefully and the results have demonstrated their value. Th1s is my first experience with an asparagus bed. So far my plants show not the slightest trace of rust.

Very truly yours,

WILLIAM E. TOWNE.

\title{
* * *
}

SOLHEM, KARLSHAMN, Sweden, July 28, 1923

To Riverview Farms:-

Our gardener, Nils Hansson, has just received your letter of July 15. He wants me to tell you that the Asparagus Roots you sent last spring arrived in perfect condition and are growing fine.

The seeds have come up about 3 inches and look fine too.

Very truly yours,

W. W. THOMAS

American Ex-Minister to Sweden

We have supplied orders for our GIANT WASHINGTON ASPARAGUS SEED and ROOTS to practically every State in the Union, Alaska, Hawaiian Islands, nearly every Dominion in Canada, several foreign countries, including England, France, Switzerland, Sweden, etc.

WASHINGTON ASPARAGUS is a particularly desirable plant because it will grow in almost every locality and climate, most kinds of soil, etc. IT IS RUST RESISTANT.

We would be pleased to fill your order which will be promptly acknowledged and carefully taken care of. Order.

Complete Cultural Directions Free With Each

\section{RIVERVIEW FARMS}

\author{
(JOS. C. SHOEMAKER)
}

BRIDGETON, N. J., U. S. A. 